\begin{tabular}{ccc}
\hline International Journal of Engineering \& Technology, $7(4.30)(2018) 363-366$ \\
SPC & Website www.sciencepubco.com/index.php/IJET \\
Research paper & Technology \\
\hline
\end{tabular}

\title{
The Effect of Dissolved Oxygen Distribution on Ammonium Nitrogen Removal in a Pilot-Scale of Vertical Upward-Flow of Aerated Electric Arc Furnace Slag Filter Systems At Various Hydraulic Loading Rates
}

\author{
Wan-Afnizan Wan-Mohamed ${ }^{1}$, Rafidah Hamdan ${ }^{1}$, Norzila Othman ${ }^{1}$, Mohd-Adib Mohammad-Razi ${ }^{1}$, Nur- \\ Shaylinda Mohd-Zin ${ }^{1}$, Nur-Ain-Nazirah Mohd-Arshad ${ }^{1}$ \\ ${ }^{1}$ Faculty of Civil and Environmental Engineering, Universiti Tun Hussein Onn Malaysia, 86400, Parit Raja, Batu Pahat, Johor, \\ Malaysia \\ *Corresponding author E-mail: afnizan@uthm.edu.my
}

\begin{abstract}
The performance of an aerated vertical upward-flow electric arc furnace slag filter (VFEAFS) system in treating domestic wastewater was examined in a warm-climate country temperature. Two pilot scale column experiments were conducted at high $\left(2.72 \mathrm{~m}^{3} / \mathrm{m}^{3} . \mathrm{day}\right)$ and low $\left(1.04 \mathrm{~m}^{3} / \mathrm{m}^{3}\right.$.day) hydraulic loading rate (HLR) set-up and the effect of different hydraulic loading levels on pollutant removal efficiency were studied. Aeration was introduced in the filter system at $10 \mathrm{~L} / \mathrm{min}$ to observe oxygen distribution concentration towards ammonium nitrogen removal. The results demonstrated that both HLR set-up were capable to achieve more than $90 \%$ ammonium nitrogen (AN) removal; however, in terms of individual efficiency of the filter system, the VFEAFS of lower HLR performed better in comparison to the higher HLR set-up. The average effluent concentration of AN by both systems were found far below standard A of Malaysian sewage discharge limit $(10 \mathrm{mg} \mathrm{NH}-\mathrm{N} / \mathrm{L})$. The results achieved in this pilot scale study indicate that removal of ammonium nitrogen in the aerated VFEAFS was explained by nitrification process, and this treatment system could be implemented to the other industryenvironmental, municipal or residential wastewater.
\end{abstract}

Keywords: Electric arc furnace slag; Dissolved oxygen; Ammonium nitrogen; Hydraulic loading rate

\section{Introduction}

Nitrogen compounds are necessity nutrients for all types of life, and also known as one of the principal pollutant in wastewater that can cause eutrophication when present in substantial quantities, causing in extreme growth of algae and other microorganisms in recipient waters such as lakes and rivers, as well as reduced dissolved oxygen concentration and toxicity to aquatic organisms [1]. Nitrogen presents in wastewater in organic and inorganic forms. Organic nitrogen can be existed in urea (eliminate ammonia from mammals when amino acids are used for energy production), amino acids (form the protein-producing peptide chain), purines, pyrimidines (involved in the manufacture of DNA), and uric acids (produced by birds and insects) [2].

Types of inorganic nitrogen includes ammonium $\left(\mathrm{NH}_{4}+\right)$, nitrite $\left(\mathrm{NO}_{2}^{-}\right)$, nitrate $\left(\mathrm{NO}_{3}^{-}\right)$, nitrous oxide $\left(\mathrm{N}_{2} \mathrm{O}\right)$ and dissolved elementary nitrogen or nitrogen gas $\left(\mathrm{N}_{2}\right)$ [3]. However, in wastewater source most of the ammonia is found in the form of the ammonium ion. Wastewater contaminated with nitrogen, especially from treatment plant, often need to be treated before released to the water body. Therefore, the elimination of nitrogen (both in reduced form and of ammonia and oxidized and nitrate form) of wastewaters to the environment has become an important necessity to protect public health and reduce the ecological risk.
New ways of elimination of nitrogen using Sharon (single reactor) for the removal of high ammonium activity on nitrite), Babe (batch of improved bioaugmentation), Anammox (anaerobic oxidation of ammonium), Canon (elimination of completely autotrophic nitrogen on nitrite) and Deammox (denitrificating oxidation of ammonium) were demonstrated in conventional treatment processes [3]. An alternative the conventional biological treatment technologies such as subsurface constructed wetlands (SSF CWs) have emerged as promising approach to treat various pollutants (organics, nutrients and heavy metals) [4]. However the nitrification process in this system is inhibited due to the insufficient dissolved oxygen that is needed as the first step for nitrogen removal in which nitrifying bacteria is competing with organics for inadequate DO [5].

In the same manner, the rock filter (RF) system which implement similar concept as in the SSF CWs system has also encountered the same problem particularly in ammonia removal because the system was easily become anoxic [6][7][8]. Considering the needs to increase oxygen availability in the RF system, a continuous aeration was introduced in the present study as it has proven in the previous research to provide sufficient oxygen, and eventually facilitate effective nitrification in the system [6]. Therefore, the present study was initiated to examine the performance of pilotscale of vertical upward-flow of aerated RF system in removing ammonium nitrogen from domestic wastewater using electric arc furnace slag (EAFS) as the filter medium. In the present study, a combination of existing wastewater treatment system; wastewater 
treatment plant (WWTP) grit tank, together with the proposed system; proposed primary tank (PPT) and aerated vertical upwardflow of electric arc furnace slag (VFEAFS) systems have shown to be a good low-cost technology for the purpose of treating municipal wastewater, specifically in removing ammonium nitrogen.

In spite of complying with the strict regulations on the elimination of nitrogen particularly ammonium nitrogen (AN) from wastewater in the Malaysian country (Environmental Quality (Sewage) Regulations 2009 (PU(A) 432) Second Schedule (Regulation 7)) (AN effluent discharge limit to river $=10 \mathrm{mg} / \mathrm{L}$ for standard A; $20 \mathrm{mg} / \mathrm{L}$ for standard B), conventional wastewater treatment systems need to be updated or the treatment scheme should be extended with a polishing treatment. Thus, the combination of conventional and aerated VFEAFS application systems can generate a high quality of final effluent with the utilization of a low-cost media technology. Ultimately this is believed to be the best alternative for removal of ammonium nitrogen in the case of small communities looking for high quality of final effluent. The research described here concerns the removal of ammonium nitrogen from wastewater treatment plant influent using an efficien and low maintenance of aerated vertical upward-flow of electric arc furnace slag (VFEAFS) filter system.

\section{Materials and Methods}

\subsection{The pilot-scale of aerated vertical upward-flow of electric arc furnace slag (VFEAFS) filter system set-up}

The pilot scale of aerated VFEAFS filter systems were constructed from 10-mm thick PVC pipe of $0.3 \mathrm{~m}$ diameter by $2.0 \mathrm{~m}$ high; allowing wastewater to flow at $1.5 \mathrm{~m}$ deep; thus leaving $0.5 \mathrm{~m}$ free space to hinder algae growth was filled with the entirely electric arc furnace slag of high $\mathrm{Ca}$ composition and placed at Taman Bukit Perdana wastewater treatment plant (WWTP), situated in Batu Pahat, Johor, Malaysia. Technically, this WWTP receives screened domestic wastewater of $90 \%$ and was largely originated from residential area of 15,800 populations equivalent (PE), and the remaining percentage (10\%) is from industrial area.

In general, this experimental study utilized a primary treatmen system (proposed primary tank) and a secondary treatment system (the vertical upward-flow). Earlier, the after pre-treatment of screened wastewater from the existing grit and grease tank of WWTP was pumped to the proposed primary tank (PPT) using Masterflex peristaltic pump, model Cole Parmer 7524-20, USA equipped with Masterflex easy load pump head, model Cole Parmer 77200-62, USA. The influent wastewater was flowed to the PPT using 25.4-mm reinforced plastic pipework and connected with polyvinyl chloride (PVC) inlet strainer.

The wastewater effluent after PPT was then permitted to flow into the pilot scale of secondary treatment systems (the vertical upward-flow systems) using similar Masterflex peristaltic pump and Masterflex easy load pump head models, located at the base of the aerated VFEAFS filter systems, and were connected with 9.7-mm Masterflex platimum-cured silicone tubing L/S 36, model Cole Parmer EW-96410-36, USA. Both filters; the VFEAFS of high $\left(2.72 \mathrm{~m}^{3} / \mathrm{m}^{3}\right.$.day) and low $\left(1.04 \mathrm{~m}^{3} / \mathrm{m}^{3}\right.$.day) HLRs were aerated using an oil-free compressor, model Jun-air International OF 30225B, Denmark supplying a 250-mm fine bubble rubber disk aerator, model Biwater Treatment, England with air flow maintained at $10 \mathrm{~L} / \mathrm{min}$. The feeding of air flow rate to the fine bubble rubber disk aerator was regularly maintained using a float-and-tube air flow meter.

The influent sample after passing pre-treatment process from the existing grit and grease tank of WWTP, as well as the effluent samples from PPT, and aerated VFEAFSs of both cases (high and low HLRs) were collected bi-weekly and analyzed for ammonium nitrogen (AN) concentrations; according to the Standard Methods for the Examinations of Water and Wastewater procedures (APHA, 2005). In addition, the in-situ parameters (dissolved oxygen, $\mathrm{pH}$ and temperature) of weekly grab samples of WWTP grit tank influent, PPT and both aerated VFEAFSs filter effluents were measured using a portable DO meter, model Hanna HI 9146, Italy and portable pH meter, model Hanna HI 991301, Italy.

Measurement of oxygen distribution taken from sampling taps at the outer surface of column filter was also conducted at different depths $(0.50 \mathrm{~m}, 0.75 \mathrm{~m}, 1.00 \mathrm{~m}, 1.25 \mathrm{~m}$, and $1.50 \mathrm{~m})$ of the aerated VFEAFSs filter systems. The purpose was to examine oxygen distribution concentration that had accommodated AN removal in both of the treatment systems. Finally, the performance of both aerated VFEAFSs on the monitored AN parameter was expressed as their percentage of removal efficiencies and computed using equation (1).

Removal efficiency $(\%)=\left[\frac{C_{\text {in }}-C_{\text {out }}}{C_{\text {in }}}\right] \times 100$

where, $C_{\text {in }}$ is the mean value of inflow concentration $(\mathrm{mg} / \mathrm{L})$ and $\mathrm{C}_{\text {out }}$ is the mean value of outflow concentration $(\mathrm{mg} / \mathrm{L})$.

\section{Results and Discussion}

\subsection{Dissolved oxygen and temperature of aerated VFEAFS filter effluents}

Scientifically, a supplement of dissolved oxygen (DO) into wastewater would stimulate a more aerobic condition to occur. When DO concentration in wastewater is significantly higher, it would then allow nitrification process to appear at a higher level. Consequently, this ideal environment would permit nitrifying bacteria to consume DO and inorganic carbon and subsequently convert ammonia to nitrite and nitrate as they are strictly aerobic. Such condition is best described in Figure 1.

In general, when oxygen of $10 \mathrm{~L} / \mathrm{min}$ was introduced in the aerated VFEAFSs systems, both of them had demonstrated high DO effluent concentrations. However, the aerated VFEAFS system which was operated at lower HLR $\left(1.04 \mathrm{~m}^{3} / \mathrm{m}^{3}\right.$.day) appeared to generate more DO effluent at range of $4.38-5.87 \mathrm{mg} \mathrm{O}_{2} / \mathrm{L}$ whilst, the higher HLR $\left(2.72 \mathrm{~m}^{3} / \mathrm{m}^{3}\right.$.day) system was able to produce DO concentration at range of $3.60-5.43 \mathrm{mg} \mathrm{O} / \mathrm{L}$. As a result, ammonium nitrogen removal was observed slightly higher in the lower HLR operation $\left(1.04 \mathrm{~m}^{3} / \mathrm{m}^{3}\right.$.day) instead of higher HLR operation $\left(2.72 \mathrm{~m}^{3} / \mathrm{m}^{3}\right.$.day) through nitrification process. A detailed fact can be visually seen in Figure 4 .

In addition, temperature has great influence towards nitrification rate as this parameter is significantly influenced the growth of nitrifying bacteria. As stated by Halling-Sørensen and Jørgensen (1993), the optimum temperature range to succeed nitrification process is $15-35^{\circ} \mathrm{C}$. Figure 2 combines the measured temperature from WWTP grit tank influent, PPT effluent, and aerated VFEAFS's effluents under different HLR conditions (1.04 and $2.72 \mathrm{~m}^{3} / \mathrm{m}^{3}$.day). The wastewater temperature effluent for both aerated VFEAFSs systems which ran at various HLR set-up were at range of $27.30-32.10{ }^{\circ} \mathrm{C}$ and $27.67-32.53{ }^{\circ} \mathrm{C}$; respectively which of course; allowing nitrification to perform at its optimum rate efficiency. 


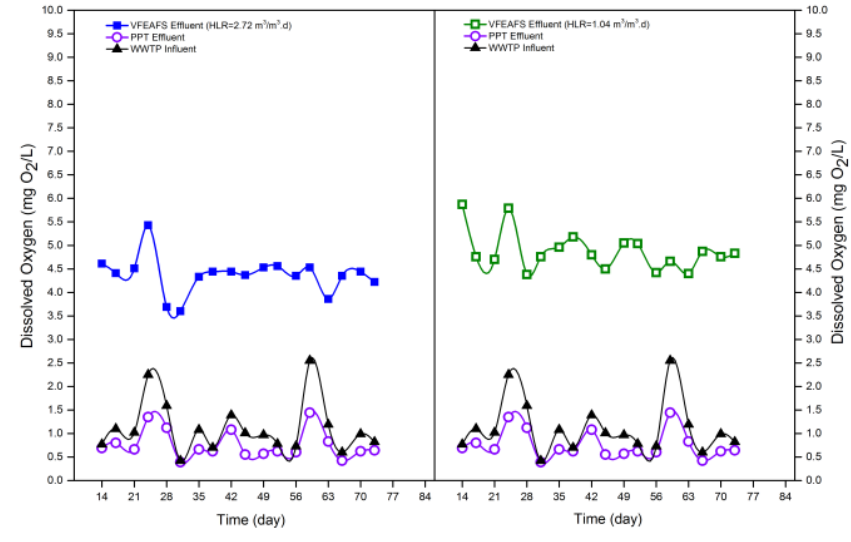

Fig. 1: DO effluent concentrations of aerated VFEAFSs systems at high and low HLR operations.

In short, the summary of the average values and standard deviation of removal efficiency of the two combined aerated vertical upward-flow of electric arc furnace slag systems (PPT + VFEAFS) which were operated at two different HLRs (2.72 and $1.04 \mathrm{~m}^{3} / \mathrm{m}^{3}$.day) are described in Table 1 . Generally, the combination of proposed primary tank (PPT) and aerated VFEAFS in treating domestic wastewater was obviously very effective in achieving high removal percentage of ammonium nitrogen (AN). The concentration of AN of both aerated VFEAFSs systems were far below the permissible limit of Standard A of sewage discharge prescribed by Malaysian Environmental Authority $\left(10 \mathrm{mg} \mathrm{NH} \mathrm{N}_{4}\right.$ $\mathrm{N} / \mathrm{L}$ ). Pollutants from domestic wastewater were removed effectively at HLR of $1.04 \mathrm{~m}^{3} / \mathrm{m}^{3}$.day after secondary treatment. On the whole, both systems operated at two different HLRs produced a high ammonium nitrogen removal (more than 90\%).

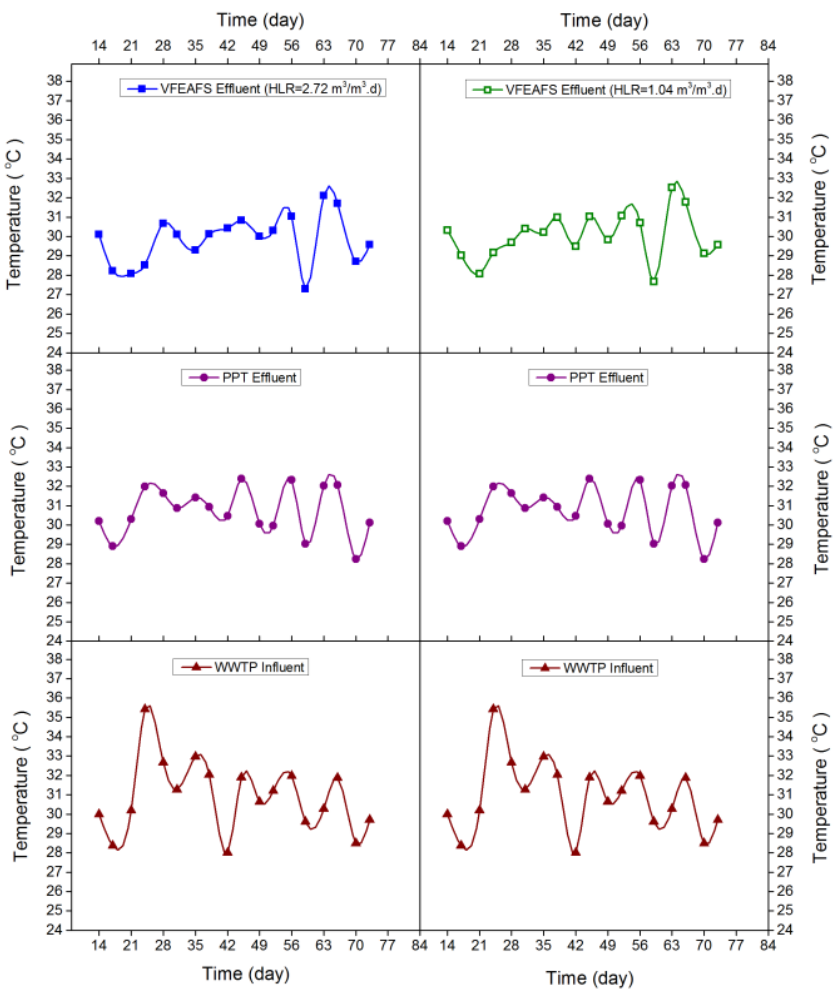

Fig. 2: Effluent temperature of aerated VFEAFSs systems at high and low HLR operations.
Table 1: Summary of statistical data for aerated VFEAFS system performance at different HLR conditions ${ }^{\mathrm{a}}$

\begin{tabular}{|c|c|c|c|c|c|}
\hline \multirow{3}{*}{ Statistical data } & \multirow{2}{*}{\multicolumn{2}{|c|}{ Sampling point }} & \multicolumn{3}{|c|}{ Parameter } \\
\hline & & & \multirow{2}{*}{$\frac{\mathbf{T}}{30.9 \pm 1.8}$} & \multirow{2}{*}{$\begin{array}{c}\text { DO } \\
1.1 \pm 0.5\end{array}$} & \multirow{2}{*}{$\frac{\mathrm{AN}}{28.6 \pm 5.7}$} \\
\hline & Influent & WWTP & & & \\
\hline \multirow{3}{*}{$\begin{array}{c}\text { Concentrations } \\
(\mathrm{mg} / \mathrm{L}) \\
(\text { mean } \pm \text { s.d) }\end{array}$} & \multirow{3}{*}{ Effluent } & PPT & $30.7 \pm 1.2$ & $0.8 \pm 0.3$ & $20.9 \pm 3.8$ \\
\hline & & $\begin{array}{c}\text { VFEAFS } \\
(\mathrm{HLR}=2.72)\end{array}$ & $29.8 \pm 1.3$ & $4.4 \pm 0.4$ & $1.8 \pm 0.4$ \\
\hline & & $\begin{array}{c}\text { VFEAFS } \\
(\mathrm{HLR}=1.04)\end{array}$ & $30.0 \pm 1.2$ & $4.9 \pm 0.4$ & $1.2 \pm 0.2$ \\
\hline \multirow{3}{*}{$\begin{array}{c}\text { Removal } \\
\text { efficiency } \\
(\%) \\
\text { (mean } \pm \text { s,d) }\end{array}$} & \multicolumn{2}{|c|}{ WWTP + PPT } & n.a & nas & $26.1 \pm 8.3$ \\
\hline & \multirow{2}{*}{$\begin{array}{l}\text { WWTP + } \\
\text { PPT + } \\
\text { VFEAFS }\end{array}$} & $\mathrm{HLR}=2.72$ & n.a & nas & $93.7 \pm 1.2$ \\
\hline & & HLR $=1.04$ & n.a & nas & $95.6 \pm 0.8$ \\
\hline
\end{tabular}

${ }^{\mathrm{a}}$ Note : All units are in $\mathrm{mg} / \mathrm{L}$ except for $\mathrm{T}=$ Temperature $\left({ }^{\circ} \mathrm{C}\right) ; \mathrm{DO}=$ Dissolved oxygen; $\mathrm{AN}=$ Ammonium nitrogen; $\mathrm{s} . \mathrm{d}=$ standard deviation $(\mathrm{n}$ $=18) ;$ n. $\mathrm{a}=$ not available; WWTP $=$ Wastewater treatment plant; PPT $=$ Proposed primary tank; VFEAFS = Vertical upward-flow of electric arc furnace slag; HLR $=$ Hydraulic loading rate $\left(\mathrm{m}^{3} / \mathrm{m}^{3}\right.$.day $)$.

\subsection{Distribution of dissolved oxygen inside the aerated VFEAFS systems at different stages}

In general, high DO levels in the treatment system would result an increase of nitrification rate. During this situation, nitrifying bacteria will become more energetic as they have an adequate DO source for the conversion of ammonia to nitrite and later to nitrate. A more specific measurement of DO distribution inside both aerated VFEAFSs systems at different height intervals revealed that the amount of DO within the aerated VFEAFS systems were consistently high. Specifically, the DO concentrations were uniformly distributed at every depth of the aerated VFEAFS column filter; each was recorded to give an amount at range of $3.90-5.77 \mathrm{mg}$ $\mathrm{O}_{2} / \mathrm{L}\left(\mathrm{HLR}=1.04 \mathrm{~m}^{3} / \mathrm{m}^{3}\right.$.day $)$ and $3.27-5.44 \mathrm{mg} \mathrm{O} / \mathrm{L}(\mathrm{HLR}=$ $2.72 \mathrm{~m}^{3} / \mathrm{m}^{3}$.day); respectively and this was illustrated in Figure 3 . Predictably, under these circumstances, the aerated VFEAFS system which was operated at lower condition (HLR $=1.04$ $\mathrm{m}^{3} / \mathrm{m}^{3}$.day) had established a slightly higher nitrification efficiency and eventually leading to higher ammonium nitrogen removal due to a greater DO concentration within the system; rather than the one at higher condition (HLR $=2.72 \mathrm{~m}^{3} / \mathrm{m}^{3}$.day). These can be visually seen in Section 3.3.

\subsection{Ammonium nitrogen (AN) removal efficiency in the aerated VFEAFSs systems}

The removal of AN was amazingly exceptional for both aerated VFEAFS systems when operated at different HLR setting conditions. Initial removal of AN was attained at an average of $26 \%$ from PPT tank effluent and their concentration was recorded at mean of $21 \mathrm{mg} \mathrm{NH} 4-\mathrm{N} / \mathrm{L}$. This concentration afterwards experienced a tremendous fall value when treated inside the aerated VFEAFSs systems. Both aerated VFEAFSs systems at different HLR conditions were discovered to give a high removal efficiency of more than $90 \%$. The average effluent concentrations of aerated VFEAFS system were recorded at range of $1.37-2.80 \mathrm{mg} \mathrm{NH}_{4}$ $\mathrm{N} / \mathrm{L}\left(\mathrm{HLR}=2.72 \mathrm{~m}^{3} / \mathrm{m}^{3}\right.$.day) and $1.00-1.49 \mathrm{mg} \mathrm{NH} 4-\mathrm{N} / \mathrm{L}$ (HLR $=1.04 \mathrm{~m}^{3} / \mathrm{m}^{3}$.day); respectively. These aerated VFEAFSs effluent concentrations were found far easily to meet Standard A requirement of Malaysian sewage discharge limit $\left(10 \mathrm{mg} \mathrm{NH} \mathrm{NH}_{4} \mathrm{~N} / \mathrm{L}\right)$. Figure 4 highlighted the pattern of influent and effluent concentrations of aerated VFEAFS systems including their removal efficiencies at dissimilar HLR condition. 


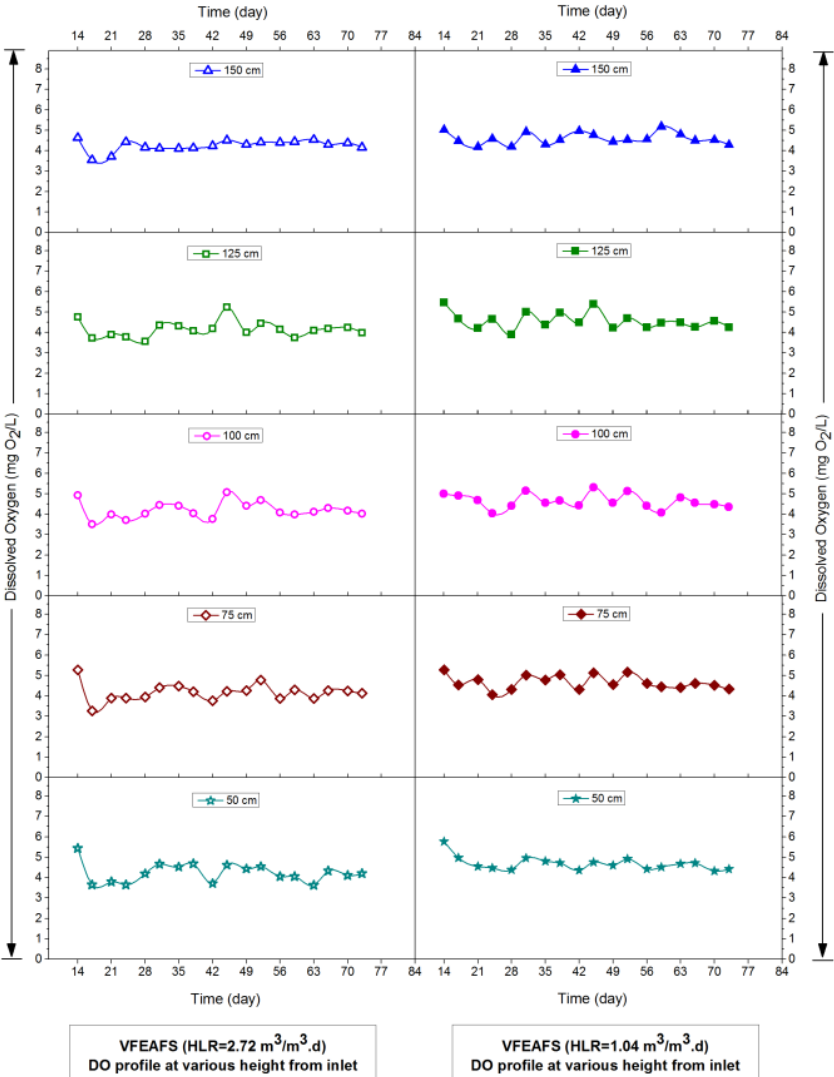

Fig. 3: DO distribution at different height intervals of aerated VFEAFSs systems under high and low HLR operations.

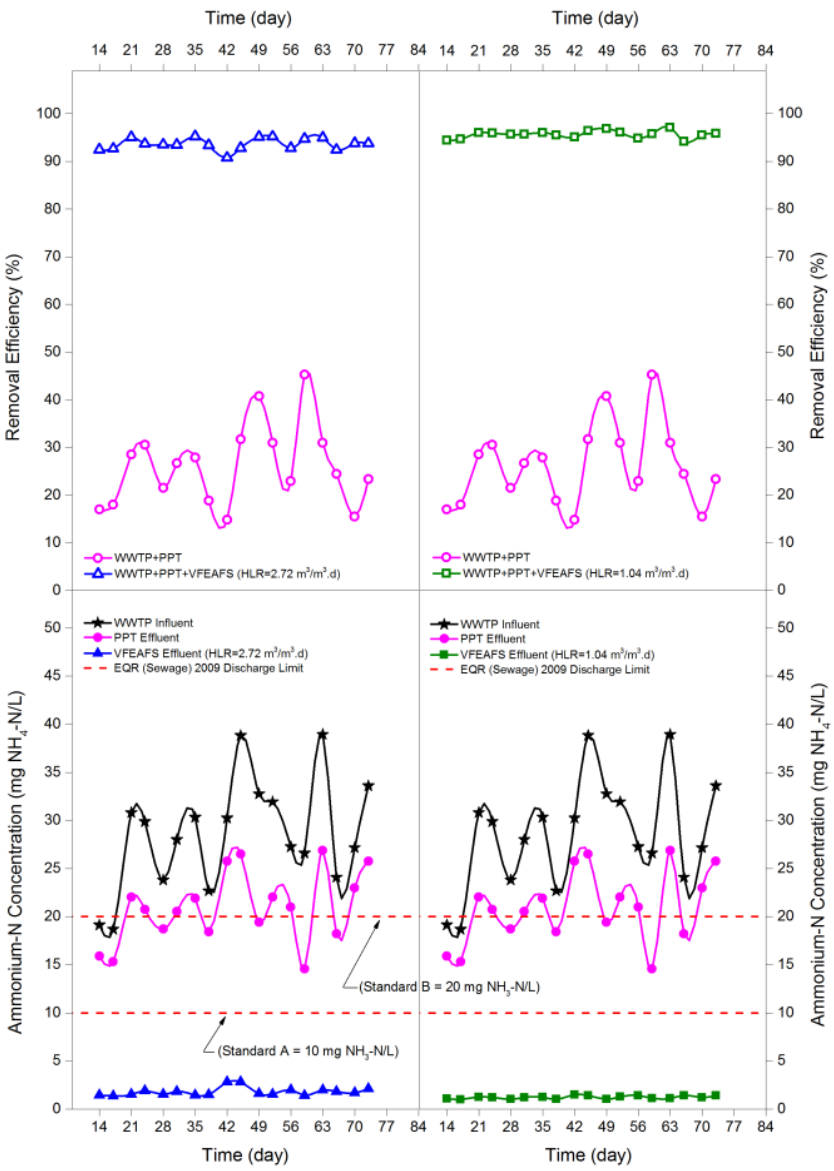

Fig. 4: AN concentrations and removal efficiencies in the influent (WWTP) and effluents (PPT and VFEAFSs) sampling locations at different HLRs.

\section{Conclusion}

In conclusion, the aerated VFEAFS system of lower HLR was evidently excellent to minimize ammonium-nitrogen concentration which accordingly, comply with Malaysian regulations of sewage discharge limit. Observably, the monitored of effluent parameters from this system demonstrated that their concentrations were steadily below the Standard A allowable limit. Meanwhile, the aerated VFEAFS system of higher HLR operation was discovered to perform almost alike the former system; however their final effluent quality was a bit greater than those operated at lower HLR setup. In the former case, higher DO effluent concentration indicate that more free $\mathrm{AN}$ ions were converted to nitrate which had eventually resulted in a high ammonium nitrogen removal. Therefore, the aerated VFEAFS system with lower HLR run of $1.04 \mathrm{~m}^{3} / \mathrm{m}^{3}$.day has appeared to be suitable technology for ammonium-nitrogen removal efficiency through nitrification process, particularly in warm climate condition such as in Malaysian country.

\section{Acknowledgement}

The authors are extremely indebted and acknowledged to all our funders especially; to Malaysian Ministry of Higher Education under Fundamental Research Grant Scheme (Vot. 1613) and Exploratory Research Grant Scheme (Vot. E031), as well as Universiti Tun Hussein Onn Malaysia. Appreciation is also given to the Antara Steel Mills Sdn. Bhd. for providing us Electric Arc Furnace Slag (EAFS) samples for this research.

\section{References}

[1] Fan J, Zhang B, Zhang J, Hao H, Guo W, Liu F, Guo Y, Haiming W (2016), Enhanced Long-Term Organics and Nitrogen Removal And Associated Microbial Community in Intermittently Aerated Subsurface Flow Constructed Wetlands. Bioresource Technology. 214: 871-875.

[2] Kadlec RH, Wallace SD (2009), Treatment Wetlands, Second Edition. CRC press.

[3] Saeed T, Sun G (2012), A Review on Nitrogen and Organics Removal Mechanisms in Subsurface Flow Constructed Wetlands: Dependency on Environmental Parameters, Operating Conditions And Supporting Media. Journal of Environmental Management. 112: 429-448.

[4] Wu H, Fan J, Zhang J, Ngo HH, Guo W, Hu Z, Liang S (2015), Decentralized Domestic Wastewater Treatment Using Intermittently Aerated Vertical Flow Constructed Wetlands: Impact Of Influent Strengths. Bioresource Technology. 176: 163-168.

[5] Fan J, Zhang B, Zhang J, Hao H, Guo W, Liu F, Guo Y, Haimin, W (2013), Intermittent Aeration Strategy to Enhance Organics and Nitrogen Removal in Subsurface Flow Constructed Wetlands. BioresourceTechnology. 141: 117-122.

[6] Hamdan R \& Mara D (2013), Aerated Blast-Furnace-Slag Filters for the Simultaneous Removal of Nitrogen and Phosphorus from Primary Facultative Pond Effluents. International Journal of Integrated Engineering. 5(1): 17-22.

[7] Foladori P, Ruaben J, Ortigar, ARC (2013), Recirculation or Artificial Aeration in Vertical Flow Constructed Wetlands: A Comparative Study for Treating High Load Wastewater. Bioresource Technology. 149: 398-405.

[8] Li F, Lu L, Zheng X, Ngo HH, Liang S, Guo W, Zhang X (2014), Enhanced Nitrogen Removal in Constructed Wetlands: Effects of Dissolved Oxygen and Step-Feeding. Bioresource Technology. 69: 395-402. 